\title{
TRANSFORMATION OF THE URBAN PATTERNS OF ISTANBUL UNDER THE EFFECTS OF THE MODERNIZATION DURING THE OTTOMAN PERIOD
}

\author{
SEVIN AKSOYLU \\ Anadolu University, Turkey.
}

\begin{abstract}
Turkey was westernized after the declaration of The Tanzimat Charter in 1839. The modernization of Ottoman Empire inevitably brought changes into the administrative, socio-economic and spatial organization of the cities as well as in the lifestyles of urban dwellers. Urbanization and economic, cultural and social modernization processes created new buildings and establishments. The spread of particular techniques and concepts of urban intervention that were developed in some Western countries and saw their influences in other Western and non-Western countries has also resulted in changes in the urban pattern. The spread of ideas and some planning approach in Turkey was due to Western engineers and architects for applying the new planning models throughout after the great fires of İstanbul in the 19th century. The implementation of Western urban planning principles and modern technology and the image of Western cities have affected the formation of new urban development and reconstruction activities in Turkish cities especially in İstanbul.

The aim of this article is to analyse the effects of planning practices initiated by the urban reforms of Tanzimat on the urban pattern of İstanbul. These analyses are based on a hypothesis, as the Turkish planning practices in the Tanzimat period were influenced by Western planning practices.

Keywords: diffusion of planning approaches, Istanbul planning, planning practices, Tanzimat Charter, urban pattern, urban reforms, westernization.
\end{abstract}

\section{INTRODUCTION}

It is a sociological truism that urbanization is associated with the process of social and economic modernization, particularly with respect to the underdeveloped societies in existence today [1-4]. Modernity reached its existing stage at the end of the industrial and West-centric enlightenment movements in the 19th century [5,6]. Urbanization and economic, cultural, social modernization processes change the physical patterns, functions, urban forms and spaces by creating new buildings and establishments. As a result, some transformations and changes in the spatial development of the countries and formation of the urban spaces occurred. Because urban space is the result of actions realized by political, economic and social decision makers, citizens and also new economic relations and administration forms necessitated important transformations in the urban structure [7]. Modernization movements in Turkey started with the declaration of the Tanzimat (reforms) decree in 1839 under the rule of Sultan Abdülmecid and ended during the reign of Sultan Abdulhamid II in 1876. There were two important reforms in this decree. One was related with the rights of the people living within the boundaries of the Ottoman Empire and the other was related with the regulation of the urban issues and administration [8]. The continuous external pressure was an important incentive for the internal administrative and legal reforms during this period [9]. Two factors were also influential in shaping the urban sphere and social relations in the Ottoman territory. One of these factors was the emergence of new international commercial relations such as the Anglo-Ottoman Commercial Treaty of 1838; the reorganization of the administrative, social

This paper is part of the Proceedings of the International Conference on Islamic Heritage Architecture and Art (Islamic Heritage Architecture 2016)

www.witconferences.com 
and cultural structure; the transformation of communication and transportation systems; and the adoption of Western lifestyle. All these factors had an influence in the transformation of the built environment and brought new urban patterns [10]. During this period, there also appeared new urban policies, a new type of urban administration, new institutions and the spread of new building types depending on the new lifestyle and transformation of the built environment [11]. The effects of this process echoed in Istanbul, which was a political, religious, social and economic centre [12]. The idea of transforming Istanbul into a modern capital and a universal city that suits itself to new conditions is one of the most remarkable features of the Tanzimat period [13]. Most of the reforms realized by the Tanzimat decree were effective on the pattern of the city and therefore the image of Ottoman/Islamic city was shattered by European effects, coming to a more cosmopolitan state [14].

This article focuses on two guidelines to structure its work: (1) to briefly analyse the context of modernity in Turkey during the Tanzimat period and (2) to evaluate the effects of modernization movements on the transformation of the urban fabric of İstanbul. In this respect, the methodology of the study is based on analysing the literature; legal documents, such as the regulations (Nizamnames), the manifestos (Illmuhaber) and the laws related to urban planning; and also the plans and maps of İstanbul during the Tanzimat period.

\section{PROGRESSIVE URBAN REFORMS DURING THE TANZIMAT PERIOD}

\subsection{Causes of urban reforms during the Tanzimat period}

The proclamation of the Tanzimat decree was followed by the implementation of some very radical and progressive reforms. As the Ottoman economy was being opened to foreign market, the influence of the European capital had increased. This contact with European countries and Western civilization through diplomatic channels and also population increase depended on the loss of land of the state and significant migration from these lost lands, necessitating some institutional reforms to re-unify the political structure of the Empire. Indeed, the population of Istanbul increased from 391,000 in 1844 to 851,527 in 1886 and reached 1,159,000 in 1901; as such the physical boundaries expanded dramatically [15-17]. Fires which had posed a great threat to the inhabitants of the city for centuries were the other significant stimulus behind the reform efforts in planning Istanbul and urban administration. Istanbul suffered with many fires for centuries and in the 19th century there had been many devastating ones (Fig. 1). While the devastation caused by large fires in cities opened the way to the rebuilding of neighbourhoods according to the new regulations, the recently founded or modern institutions were housed in newly planned areas of the city. According to the Tanzimat reformers, the destroyed areas were ideal empty spaces to implement their experiments on Istanbul's urban image. In fact, the basic grid plans were applied to these neighbourhoods during the reconstruction operations of this period. Alongside the other areas of political and administrative change, the Tanzimat spirit also had an influence on the transformation of the built environment. The fusion of Tanzimat's centralizing reform into the city was by means of urban management and physical reformation of the urban fabric which was in accordance with 19th-century urban planning principles.

Being the capital of the Empire and a port city at the same time, Istanbul was the first city to feel the consequences of these reforms. The idea of making Istanbul a modern capital and a universal city that suits itself to new conditions is one of the most remarkable features of the Tanzimat Reform era [13]. Reform regulations, organizations and urban design projects for İstanbul are as follows. 


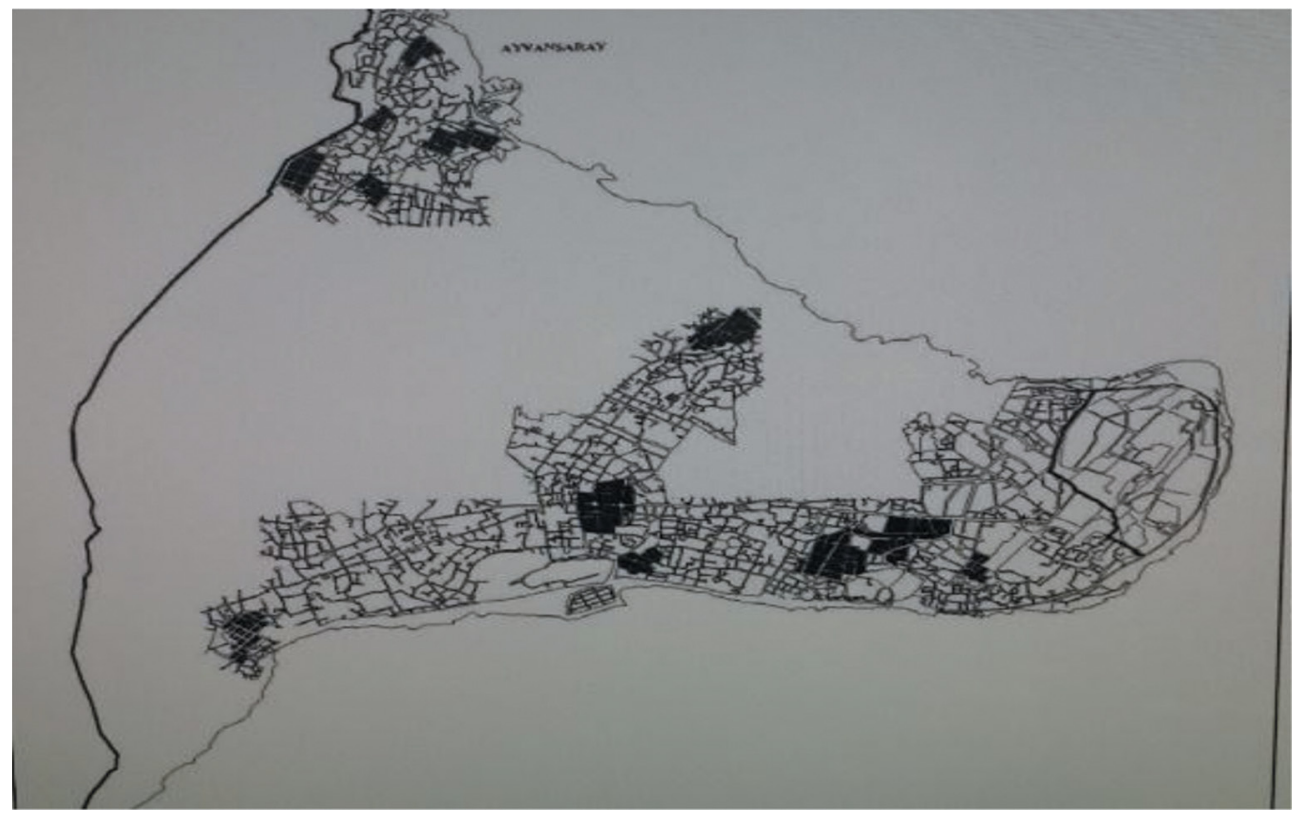

Figure 1: Areas of İstanbul devastated by fire (bold parts show the fire areas [18]).

\subsection{Legal aspects of the purpose of modernizing İstanbul}

The Ottoman reformers had started introducing rules concerning street widths, elimination of dead ends and building materials months before the declaration of the Tanzimat decree. The first official document which was called İlmuhaber had been prepared on 17 May 1839 just a few months before the announcement of the Tanzimat decree. It provided the specifications and regularization of streets according to their width; the need for, and design of, pedestrian pathways; restrictions on timber buildings; encouragement of masonry construction; and the promotion of a series of hierarchal planning controls for construction works in the city [19]. In later years, further regulations that were aimed at changing the urban fabric of cities, primarily Istanbul, were issued.

Seven major regulations were passed between 1848 and 1882. These were Building Regulation (Ebniye Nizamnamesi) of 1848, I stimlak Nizamnamesi (Regulation for Expropriation) of 1856, Sokaklara Dair Nizamname of 1859 (Regulation on Streets), Turuk ve Ebniye Nizamnamesi in 1863 (Street and Building Code), I stanbul ve Belde-i Selasede Yapılacak Ebniyenin Suret-i I nşaiyesine Dair Nizamname in 1875 (Regulation on Construction Methods in I stanbul), Dersaadet Belediye Kanunu in 1877 (Municipal Law of I stanbul) and Ebniye Kanunu in 1882 (Building Law) [14, 20, 21]. The Building Regulation (Ebniye Nizmanamesi) provided standardization and restriction in building works and development control in terms of street width, setbacks from the site boundaries, height limitation and some technical requirements to prevent fire. The Building Law (Ebniye Kanunu) included some articles related to roads, fire areas and buildings. The goals of these regulations pinpointed a city with straight and uniformly wide streets defining rectangular or square blocks composed of stone or brick buildings. The application of these regulations in the districts of Galata, Aksaray, etc. resulted in the imitation of the straight and wide arteries of Paris, and patterns adopted from contemporary European trends. 
2.3 Urban design projects for the purpose of modernizing İstanbul

In the process of urban reform in Istanbul, architects and engineers were invited from Europe to prepare the maps of the capital. From the 19th century to the proclamation of the Second Constitutional Period (1908), three major urban design projects had been improved for the purpose of modernizing the city. These projects were proposed by Helmuth von Moltke, F. Arnodin and Joseph Antoine Bouvard. The main themes of city planning of Istanbul from 1838 to 1911 were illustrated in Von Moltke's and Bouvard's plans. The proposed image of these plans was European with their straight, wide streets leading to the historical monuments, regularized embankments and large public squares, whereas the fabric of the Ottoman cities included narrow, organic street pattern, cul-de-sacs. Applying the Haussmanian approach to this texture caused the destruction of many historic buildings and monuments and the introvert lifestyle which was created by this characteristic [22]. As seen from Fig. 2, the significance of Von Moltke's projects is to conceive İstanbul as an integral and complete entity [14].

\subsection{Urban reforms related to urban administration in İstanbul}

The pre-modern cities of the Ottoman Empire lacked a unified authority that took care of the administration of urban space. Hence, urban reforms in Istanbul began with the urban administration [19]. 'Şehremaneti', which was basically the Ottoman version of the French 'préfecture de la ville', was established in 1855. Şehremaneti aimed at 'facilitating the provision of goods and determining the prices as well as undertaking the cleaning of the city' [23]. Şehremaneti was far from answering the needs of people since it failed to produce tangible developments and thus, a new step was the establishment of Intizam-1 Şehir Komisyonu (Commission for the Regulation of the City) in 1855. The commission aimed to maintain the embellishment, cleaning and expansion of roads, illumination of streets, repair of pavements and the improvement of building styles of Istanbul [14]. Due to the lack of experience as well as the scarcity of financial resources necessary to maintain the promised municipal services, Şehremaneti and İntizâm-1 Şehir Komisyonu failed, and a second commission was

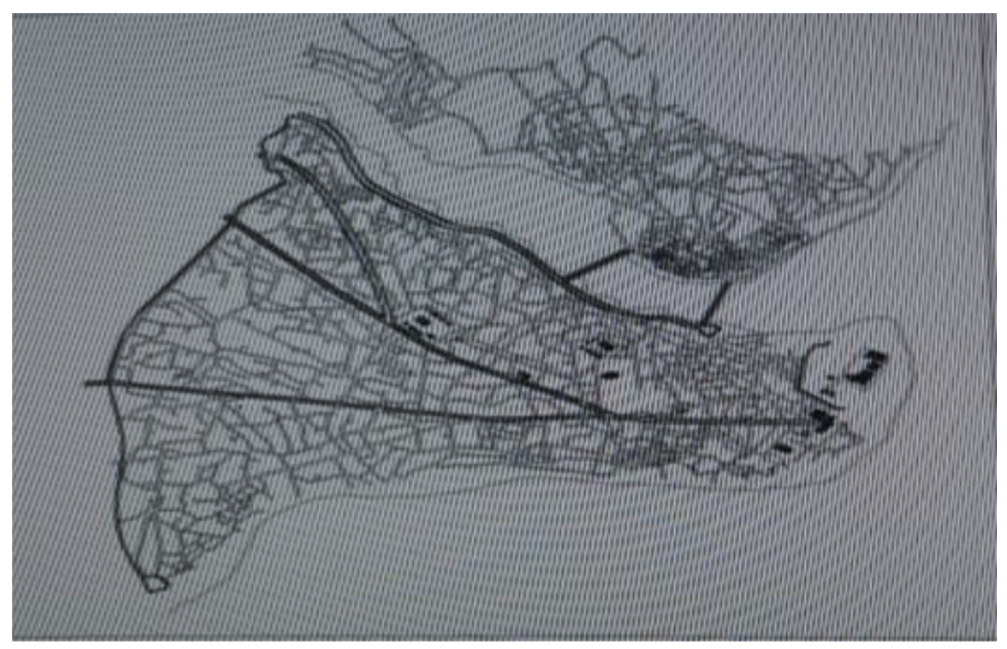

Figure 2: Urban plan designed by Von Moltke.

Source: This map was obtained from the archive of Istanbul Metropolitan Municipality. 
established in 1858. The demands of the commission for wider autonomy and more diverse financial resources resulted in the establishment of the sixth municipal district comprising Galata, Beyoğlu and Tophane being adopted as a pilot before the implementation of the new arrangements in the other 13 divisions in 1858. The European influence was so overwhelming during the whole process that even the name of the district was an imitation of the Sixth arrondissement of Paris [23]. The government decided that municipal administration would be expanded to include the whole city in 1868. Finally in 1877, Regulation for the Municipal Administration of Istanbul was issued which ordered the establishment of all municipal districts, therefore making the Sixth Municipal District subject to the same rules with the others.

\section{TRANSFORMATION OF URBAN FABRIC OF ISTANBUL DURING THE TANZIMAT PERIOD}

As seen from Fig. 3, in the 19th century Istanbul had three main regions. The first region was the historic peninsula - walled city. The second was the Galata-Pera region at the opposite side of the historic peninsula and finally the third was the Anatolian region, consisting of the Üsküdar, Kadıköy and Haydarpasa districts. Galata and Pera were the representations of the modern, Western facade of the city, and the historic peninsula was the site of traditional and predominantly Muslim groups [24]. The urban renovation projects in the historic peninsula due to the fires, the modernizing reforms and population growth led to the transformation of the urban fabric.

\subsection{Transformation of housing areas from individual to multiple housing units in İstanbul}

Before the Tanzimat decree, the residential areas and the building activities were limited in İstanbul. Beginning from 1839 the building activities, especially in Galata and Pera, were accelarated [24]. Initiation of new property laws in the 19th century eased private property

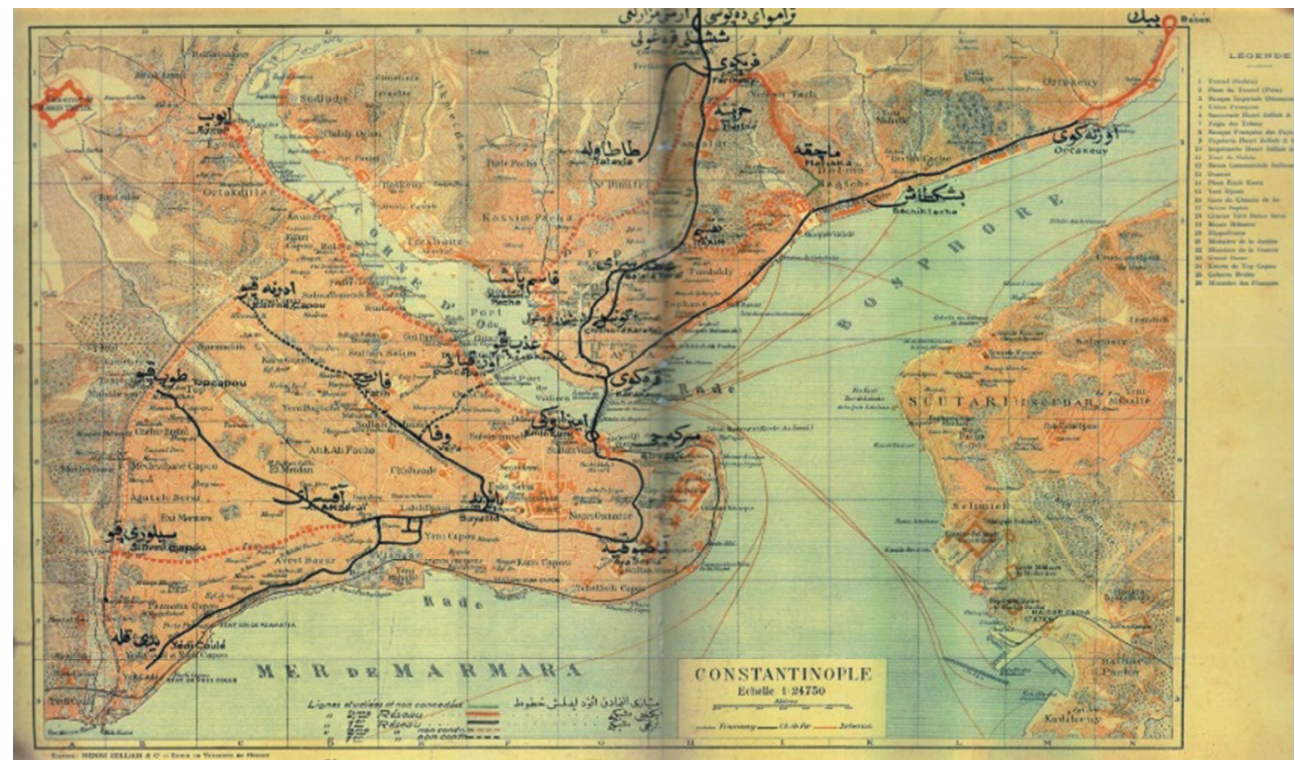

Figure 3: Regions of İstanbul during the Ottoman period.

Source: http://tarihvemedeniyet.org/2009/07/osmanli-arsivinden-orjinal-haritalar.ht. 
ownership and made the transformation of Istanbul residential areas possible [25, 26]. In the traditional residential pattern of the Ottoman Empire, ethnicity and religion were influential in the urban segregation [27]. With increasing division of labour and the differentiation of social strata, the city's residential pattern became socially and spatially segregated. This shift brought along new housing types such as luxurious apartment buildings, row houses and villas (köşk) [28, 29]. Villas of the Ottoman Pashas on the seashores and the Europeanstyle apartment houses of the Levantine and non-Muslim bourgeoisie were the symbols of bureaucrats' and bourgeoisie's social and cultural influence on the socio-spatial fabric of the city. At a greater scale, the diffusion of apartment blocks was seen together with the change in urban fabric and social and cultural transformation. Early apartment houses which reflected a Western and modern lifestyle emerged in the most prestigious sections of Galata and Pera [30]. The fact that Muslim Ottomans delayed participation in the apartment living and apartment blocks were not constructed in historical peninsula earlier than 1922 justifies this position [21, 31-33]. The demographic growth along with the factors mentioned above and the new settlement areas were scattered from Taksim to Şişli, from Tophane to Dolmabahçe, and lastly from Dolmabahçe to Beşiktaş, Teşvikiye and Nişantaşı quarters located in the European side [34] (see Fig. 4). The shores of the Bosphorous and Golden Horn became new residential areas for the Ottoman elite. Ottoman bureaucrats and foreigners who were dwelling in the new apartment houses or the wooden villas were located in the peripheral areas of the city [35].

The shores of the Golden Horn began to lose prestige and transform into a slum area due to the construction of military barracks, industrial plants and dockyards. Construction type of the houses and the pattern of the residential areas also changed during this period. All buildings to be constructed in the future were not to be built of timber and would no longer be constructed without plans. Muslims and non-Muslims who want to construct a masonry house shall be provided with sites which are regularized according to geometrical rules and have large streets. These houses shall not be more than three storeys or $16.5 \mathrm{~m}$ in height and no cantilevered balcony is permitted. In principle, houses should be of masonry; however,

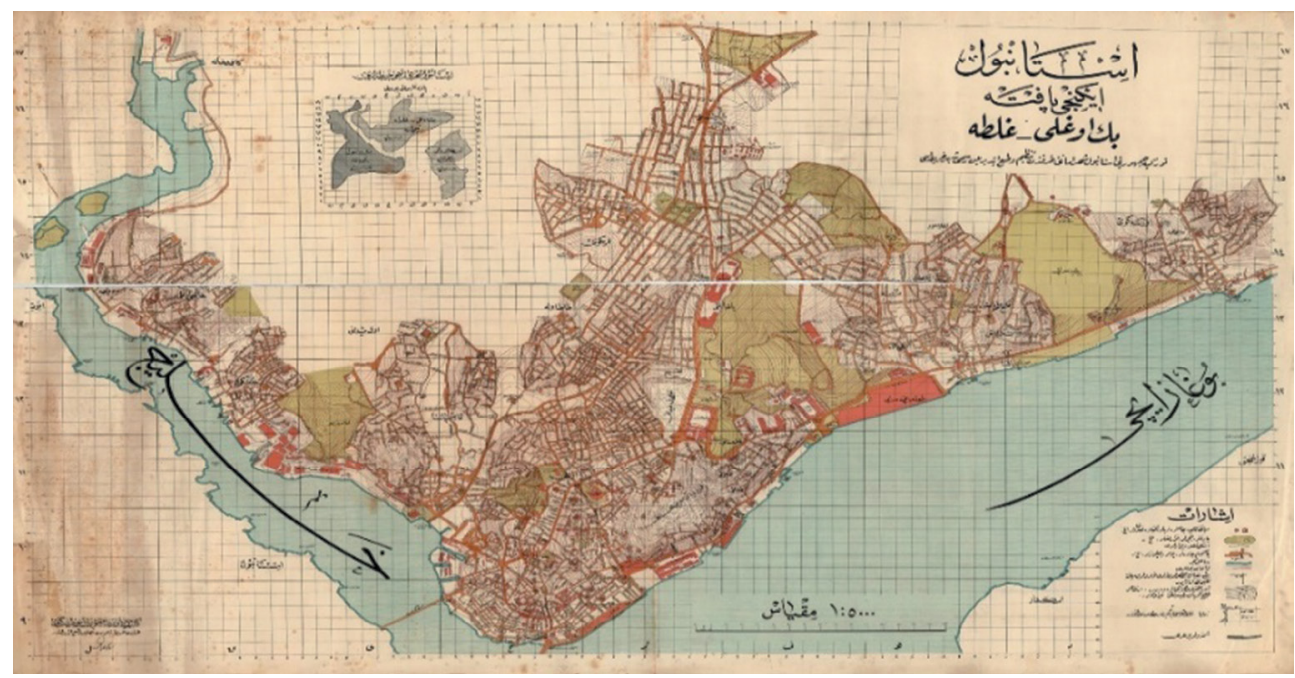

Figure 4: Development of new quarters towards Teşvikiye and Nişantaş1.

Source: http://www.esplanlama.com/english/GalleryMap.aspx. 
someone who cannot afford to build a masonry house can construct a timber house [23]. The height and the proportion of houses were regulated according to the construction material and according to which part of town the building was constructed in.

\subsection{Transformation of streets and squares}

The traditional street system of İstanbul was narrow, main streets and alleys ending with the cul-de-sacs in the residential areas. As the Turkish city was rebuilt and reorganized to cope with the new and expanding traffic that filled its streets, the whole country was transformed by the new network of railways and roads [3]. The application of the reform regulations and projects in İstanbul resulted in the imitation of the straight and wide arteries of Paris and patterns adopted from contemporary European trends. Expropriation was also a new practice to be implemented to enable the widening of the streets. Hence, it provided sufficient space for a regular street network. While the main arteries were to be constructed $15 \mathrm{~m}$ (20 zira) in width, the rest of the streets were to be $9-12 \mathrm{~m}$ (12 and 15 zira) or at least $7.5 \mathrm{~m}$ (10 zira) in width. Depending on these restrictions, many roads were widened by destroying buildings and monuments around them. One of the main arteries in the proposed network was Divanyolu which connected the main gate of the Topkap Palace to the gate on the Theodosian walls (Fig. 6). No cul-de-sacs were permitted. The roads were to be planted with trees and provided with pedestrian footpaths which were to be $3 \mathrm{~m}$ (4 arşın) in width. In appropriate locations, the masonry wharves shall be provided with squares. But the changes in the street layout and the urban fabric did not affect the urban image of the city significantly. Because the fires determined the boundaries of regularization, wide and straight arteries were scatterd unevenly depending on the location of the burntup areas, and interconnections between the individually replanned neighbourhoods were not addressed [14, 37] (Fig. 5).

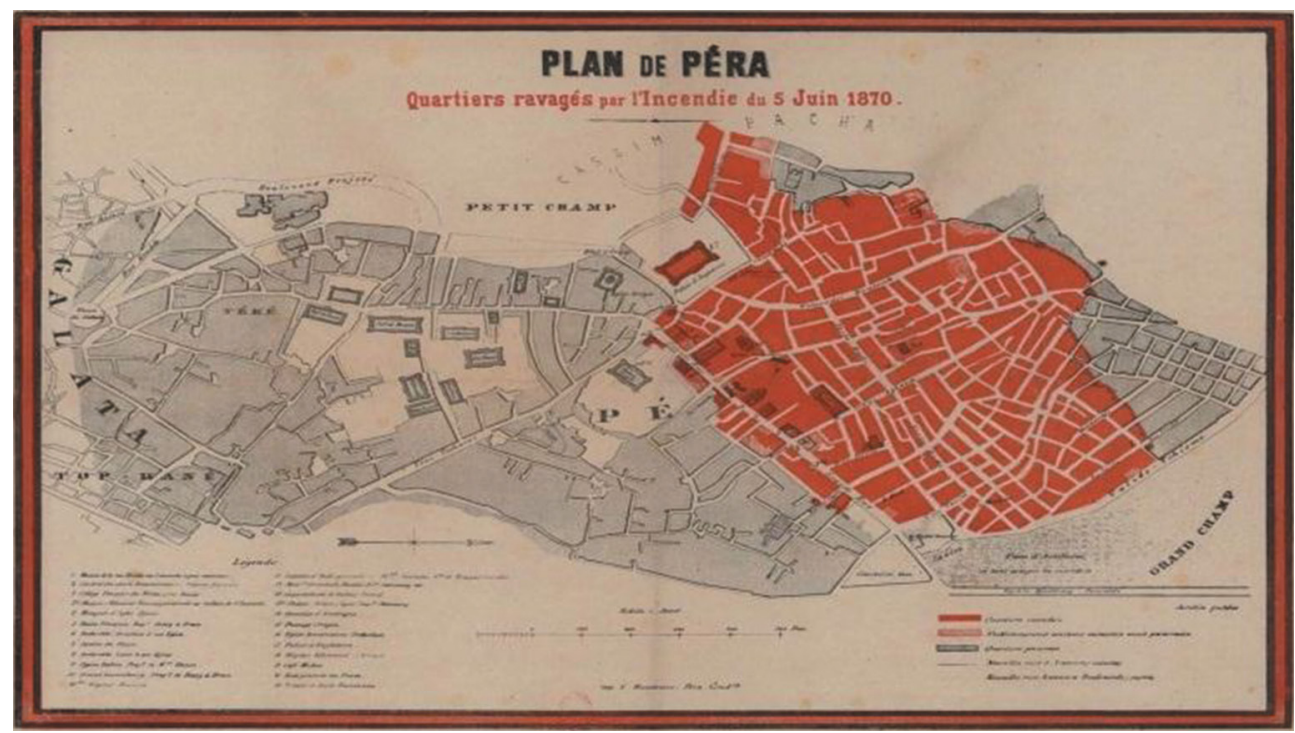

Figure 5: Street pattern of Pera after the fire (while the grey part shows the old pattern, the red part shows the new urban pattern of Pera).

Source: This map was obtained from the archive of Bibliotheque Nationale De France. 


\subsection{Formation of new city centres and neighbourhoods}

Up to the 1870s, Istanbul modernizers focused on laying out and building streets, as well as on enforcing new building regulations. Parallel to socio-economic developments, several new public and private enterprises and new financial organizations such as companies and new bank buildings and custom facilities were established in Istanbul and its surroundings after the 1870 s with an effect on the urban texture [38,39]. Galata, Beyoğlu and Tophane regions needed immediate attention since it was the focal point of embassies, foreign banks and schools [40]. Many buildings were incorporated into cityscapes. While the traditional shops were mainly located in the historical peninsula, shopping and entertainment business firms, large stores and banks were all opened in Galata-Pera district [41]. The Bosphorus shores and the Anatolian side were used for leisure and recreational activities. Alongside the enlarged and paved roads, new urban places and amenities like cafés, opera houses, shops, theatres, restaurants, beer halls, hotels and bookstores were established [42]. Educational buildings became more varied since the transformation of the education system. Since the urban area extended, cemeteries remained within the development areas. Hence, they were moved to the peripherial areas and transformed into parks which were designed by considering the Western models.

\section{CONCLUSION}

Increasing economic relations with the European countries transformed the Ottoman Empire into an open market for foreign traders. The nineteenth century was a period of fast socioeconomic transformations which also altered the character of pysical environment in Turkey. This process showed the effects in Istanbul which was a political, religious, social and economic centre of the Ottoman Empire. The idea of transforming Istanbul into a modern capital and a universal city that suits itself to new conditions is one of the most remarkable features of the Tanzimat period. Most of the reforms realized by the Tanzimat decree were effective on the pattern of the city and therefore the image of Ottoman/Islamic city was shattered by European effects, coming to a more cosmopolitan state. There are important differences between the transformation of historical peninsula and Pera-Beyoglu with respect to the westernization movements. The urban renovation projects in the historical peninsula were 'patchy' applications because the project areas were limited to the burnt spaces. Furthermore, a new middle class of bourgeoisie emerged as a social outcome of the modernization process. The new
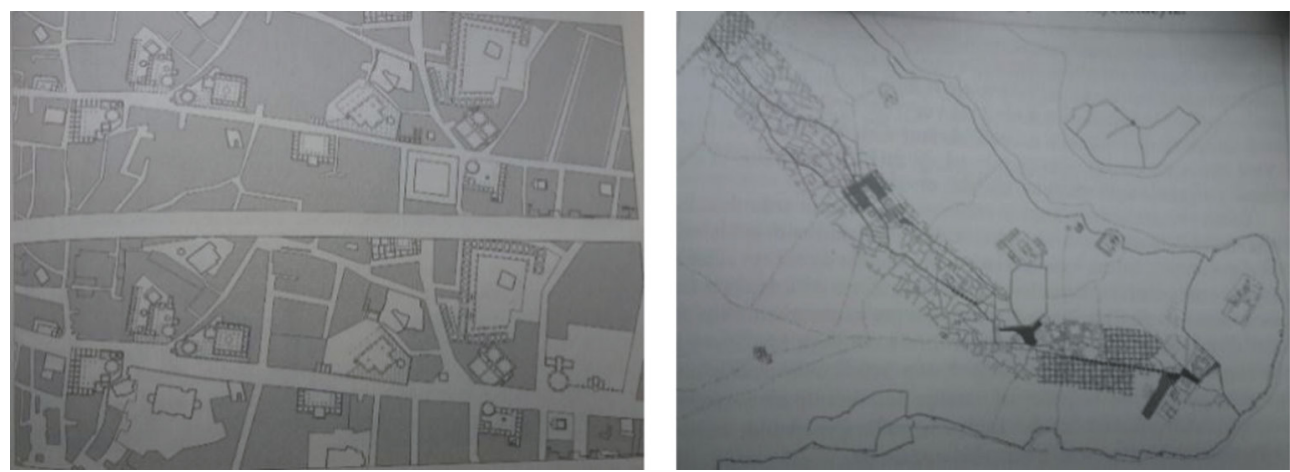

Figure 6: Divanyolu before and after widening of the road (in the second picture, checkered parts show the destroyed areas) [36]. 
citizen needed new social spaces to circulate, and new public spaces in Istanbul. New military and civilian hospitals, theatres, hotels, railroad stations, coffee houses and restaurants were thus incorporated into cityscapes.

\section{REFERENCES}

[1] Hauser, P.M.P. (ed.), Urbanisation in Asia and the Far East, UNESCO: Calcutta, p. 15, 1957.

[2] Hoselitz, B.F., Sociological Aspects of Economic Growth, Free Press: Glencoe, Ch. 7, 1960.

[3] Lerner, D., The Passing of Traditional Society, Free Press: Glencoe, pp. 64-67, 1958.

[4] Sjoberg, G., The rural-urban dimension in preindustrial, transitional and industrial societies. Handbook of Modern Sociology, ed. R.E.L. Faris, Rand Mc Nally: Chicago, 1964.

[5] Hall, S., Modernity and Its Futures, Polity Press in Association with David Held, Tony Mc Grew with the Open University: Cambridge, 1992.

[6] Arıtan, Ö., Rus modernleşmesi, mekan ve edebiyat, Dostoyevski 'yer altından notlar' Zamyatin: 'Biz'. Arredamento Mimarlık, Boyut Yayın Grubu: İstanbul, 2001/10.

[7] Nasr, J. \& Volait, M., Urbanism-Imported or Exported, Introduction: Transportation Planning, Wiley-Academy: West Sussex, England, 2003.

[8] Denel, S., Batılılasma Sürecinde Ístanbul'da Tasarım ve Dış Mekânlarda Degisim ve Nedenleri, METU: Ankara, p. IX, 1982.

[9] Zürcher, E.J., Turkey a Modern History, I.B. Tauris \& Co. Ltd. Publishers: London, Oxford, New York, pp. 317-318, 1998.

[10] Keyder, C. \& Oncu, A., Kuresel ekonomiye entegrasyon sureci, Istanbul yol ayrımında. Istanbul Dergisi, 7 (28), p. 35, 1993.

[11] Güney, E.E., A study on the effect of transportation systems to the evolution of the city image - the case of Istanbul. Megaron, 7(1), pp. 91-107, 2012.

[12] Eryılmaz, B., Tarihte İstanbul'un çok kimlikli yapısı, Habitat II Kent Zirvesi, İstanbul'96, İstanbul, 03-12 June 1996, Istanbul Metropolitan Municipality Publications, I(44), pp. 186-189, 1997.

[13] Batur, A., İstanbul'da kültürel mirasın korunması ve yaşatılması, in Dünya Mirası Gelişmeler-Sorunlar Çözüm Önerileri/Teknik Kongre, TMMOB Mimarlar Odası İstanbul Büyükkent Şubesi Yayınları, p. 57, 2006.

[14] Çelik, Z., The Remaking of Istanbul: Portrait of an Ottoman City in the Nineteenth Century, University of California Press: Berkeley, p. 51, 1993.

[15] Buluktekin, M.B., A city right at the core of global, political, economical and social changes of the 19th century: Istanbul, Dicle Üniversitesi Hukuk Fakültesi Dergisi, DiyarbakırCilt: 19, Say1: 30-31, Y11: 2014.

[16] Tabakoğlu, A., Ístanbul'un Iktisadi ve Içtimai Tarihi, İstanbul, p. 350, 2012.

[17] Karpat, K., Osmanlı Nüfusu (1830-1914), Second edition, Timaş Publications: Istanbul, p. 219, 2010.

[18] Ayverdi, E.H., 19. Asırda Istanbul Haritası, Fetih Cemiyeti Yayınları: İstanbul, 1978.

[19] Sahara, T., The Ottoman City Council and Beginning of the Modernization Of Urban Space in the Balkans in the City in the Ottoman Empire - Migration and the Making of Urban Modernity, Routledge: London, 2011.

[20] Ergin, O., İstanbul'da Türklerin beş asırlık imar ve iskan hareketleri. İstanbul: İstanbul Belediye Mecmuası, 14(163-165), p. 814, 1938. 
[21] Tekeli, I., The Development of the Istanbul Metropolitan Area: Urban Administration and Planning, Kent Basımevi: İstanbul, 1994.

[22] Aksoylu, S. \& Ateş, S., Changes in the historical layout of cities in Turkey related to modernisation movements and the dissemination of foreign planning concepts. Proceedings of the IGU Urban Geography Commission (Urban Challenges in a Complex World), Johannesburg and Stellenbosch, pp. 12-27, 2014.

[23] Ergin, O.N., Mecelle-i Um̂ur-i Belediyye, IBB Kültür İşleri Daire Başkanlığı Yayınları: İstanbul, 1995.

[24] Akın, N., 19. Yüzyılın Íkinci Yarısında Galata ve Pera, Literatür: Istanbul, 1998.

[25] Öncel, A.D., Apartman, Galata'da Yeni Bir Konut Tipi, Kitap Yayınevi: İstanbul, pp. 9-10, 2010,

[26] İgüs, E., XVIII. Yüzyıl İstanbul'unda fiziki çevre, meydan çeşmeleri ve çeşme meydanlarının etrafinda oluşan İstanbul meydanları. I. Uluslararası Osmanlı İstanbulu Sempozyumu, İstanbul, pp. 674, 2014

[27] Tekeli, İ., Modernite Aşılırken Kent Planlaması, İmge Kitabevi: Ankara, 2000.

[28] Shirine H., Şehr-i Sefa 18. Yüzyılda İstanbul, İletişim Yayınları: İstanbul 2010, p.20.

[29] Danış, D. \& Kayaaalp, E., Elmada ̆̆:A Neighborhood in Flux, Institut français, open edition boks d'études anatoliennes (Chapter 2), Istanbul, 2004.

[30] Aktuna, Z., Re-reading the social context of apartment block development in Istanbul :1889-1922, Unpublished Master Thesis, METU, Ankara, 2003.

[31] Ünal, M., Türkiye'de apartman olgusunun gelişimi: İstanbul örneği, Çevre, TemmuzAğustos, pp. 71-77, 1979.

[32] Kuban, D., Kentin gelişmesi, dünden bugüne İstanbul ansiklopedisi, Vol. IV, Türkiye Ekonomik ve Toplumsal Tarih Vakfi, pp. 527-547, 1995.

[33] Yücel, A., Typology of urban Housing in 19th Century İstanbul, Housing and Settlement in Anatolia: A Historical Perspective, Türkiye tarih vakfi: İstanbul, 299-300, 1998.

[34] Attila Yücel, İstanbul'da 19.uncu yüzyüzyılın kentsel konut biçimleri'. Tarihten Günümüze Anadolu'da Konut veYerleşme, ed. Yıldız Sey, Tarih Vakfi Yurt Yaydnları: Istanbul, 1996.

[35] Tanyeli, U., Yeni Topluma Yeni Konut' in Üç Kuşak Cumhuriyet, Tarih Vakfı Yayınlar: Istanbul, p. 140, 1998.

[36] Cerasi, M., Divanyolu, Kitap Yayınevi: İstanbul, pp. 147, 151, 2006.

[37] Tekeli, İ., II. Dünya savaşı sonrasında Türkiye'nin kent planlaması pratiğindeki gelişmeler. Derleyen: Perihan Kiper, Ü.Nevzat Uğurel, İmar Planları Yapım ve Uygulama Süreçleri. Şehir Planlama Mimar ve Mühendisleri Odası, Ankara, 1980.

[38] Genç, M., 19. Yüzyılda Osmanlı iktisadî dünya görüşünün klasik prensiplerindeki değişmeler. Divan, Bilim ve Sanat vakfi Yayınevi, İstanbul, (1), p. 7, 1999.

[39] Rosenthal, S.T., The Politics of Dependency: Urban Reform in Istanbul, Greenwood Press: Westport, CT, p. 11, 1980.

[40] Ortaylı, İ., Tanzimat Devrinde Osmanl Mahalli İdareleri (1840-1880), Türk Tarih Kurumu: Ankara, p. 142, 2000.

[41] Berkmen, Y.H., Küreselleşen Kentte Küreselleşemeyen Çarşılar, Dergisi Sayı, Tarih Vakfi Yurt Yayınları: İstanbul, p. 119, 2000.

[42] Yumul, A., A prostitute lodging in the bosom of Turkishness: Istanbul's pera and its representation. Journal of Intercultural Studies, 30(1), p. 59, 2009. DOI: $10.1080 / 07256860802579444$. 